\title{
Perbandingan Jenis Sampah Terhadap Lama Waktu Pengomposan Dalam Lubang Resapan Biopori
}

\author{
Oleh : Sri Widyastuti *)
}

\begin{abstract}
Abstrak
Lubang resapan biopori "diaktifkan" dengan memberikan sampah organik. Sampah ini akan dijadikan sebagai sumber energi bagi organisme tanah untuk melakukan kegiatannya melalui proses dekomposisi. Sampah yang telah didekompoisi ini dikenal sebagai kompos. Dengan melalui proses seperti itu maka lubang resapan biopori selain berfungsi sebagai bidang peresap air juga sekaligus berfungsi sebagai "pabrik" pembuat kompos.

Jenis sampah yang dimasukkan akan mempengaruhi kecepatan proses pengomposan yang ditandai dengan kecepatan menurunnya ketinggian sampah dalam lubang resapan biopori. Dengan semakin cepat terjadi penurunan ketinggian sampah maka lubang resapan akan dapat digunakan setiap hari.

Berdasarkan hasil penelitian diperoleh data: (1) lubang resapan biopori yang diisi sampah daun akan membutuhkan waktu 1 bulan untuk membusuk, (2) lubang resapan biopori yang diisi sampah daun kering dan sampah dapur atau sisa makanan butuh waktu 7 hari untuk terjadi dekomposisi sedangkan (3) lubang resapan biopori yang diisi sampah dapur saja akan mengalami proses dekomposisi dalam waktu 1- 3 hari.
\end{abstract}

Kata Kunci : jenis sampah, pengomposan, lubang resapan biopori

\section{PENDAHULUAN}

\section{A. Latar Belakang Masalah}

Manusia banyak melakukan perubahan pada sifat permukaan lahan, diantaranya dengan membangun lapisan kedap di atasnya berupa tapak bangunan (rumah, perkantoran, dan fasilitas umum), jalan dan pengerasan lain, sehingga bagian air hujan yang masuk kedalam tanah semakin banyak berkurang dan bagian air hujan yang menjadi aliran permukaan semakin meningkat. Perubahan porsi bagian hujan yang menjadi aliran permukaan ini menjadi pemicu utama terjadinya banjir (http://www.surya.co.id).

Konversi penggunaan lahan menjadi pemukiman menyebabkan fungsi hidrologis tanah terganggu. Sebagian permukaan lahan menjadi kedap karena tertutup tapak bangunan, jalan, dan pengerasan lainnya. Bagian lahan terbuka juga mengalami proses pemadatan, dan biopori berkurang karena berkurangnya tanaman dan fauna tanah sebagai pelaku pembuat biopori di dalam tanah. Hal ini mengakibatkan sebagian besar air hujan tidak lagi meresap ke dalam tanah dan bahkan dibuang melalui saluran drainase. Peningkatan jumlah air hujan yang mengalir di permukaan tanah karena berkurangnya laju peresapan air ke dalam tanah, akan menyebabkan banjir pada musim hujan dan kekeringan pada musim kemarau, serta berkurangnya cadangan air bawah tanah.

Teknologi konvensional yang telah diperkenalkan untuk peresapan air di kawasan pemukiman adalah pembuatan sumur resapan. Sayangnya, dengan teknologi seperti ini tidak semua orang dapat menerapkannya. Sumur resapan memerlukan dimensi cukup besar, sebagian dindingnya perlu dibuat penguatan serta perlu diisi dengan pasir, kerikil, dan ijuk. Hal ini dilakukan untuk menghindari longsornya dinding resapan. Bahan pengisi seperti itu tidak dapat digunakan oleh biota tanah sebagai sumber energi dalam penciptaan biopori. Oleh karena itu, dalam kasus sumur resapan biopori boleh dikatakan tidak akan terbentuk.

Penyumbatan permukaan resapan oleh bahan-bahan halus yang terbawa air dan tersaring oleh ijuk sehingga menyumbat rongga diantara ijuk sangat beresiko terjadi, hal ini akan menyebabkan laju peresapan air menjadi berkurang.

\footnotetext{
*) Dosen Teknik Lingkungan

Universitas PGRI Adi Buana Surabaya
} 
Pengumpulan volume air yang cukup besar dalam sumur resapan menyebabkan beban resapan relatif besar. Beban resapan adalah volume air yang masuk dalam lubang dibagi luas permukaan resapan (dinding dan dasar lubang). Beban resapan akan meningkat sejalan dengan peningkatan diameter lubang. Peningkatan beban resapan mengakibatkan penurunan laju peresapan air karena terlalu lebarnya zone jenuh air di sekeliling dinding lubang, apalagi bila sebagian permukaan resapan dikedapkan dengan penguat dinding.

Mengingat kebutuhan air yang terus meningkat dan sumber air utama berasal dari curah hujan, perlu diupayakan rekayasa teknologi peresapan air tepat guna yang dapat efektif meresapkan air hujan ke dalam tanah. Peresapan air hujan yang efektif akan dapat memelihara kelembaban tanah, dan menambah cadangan air bawah tanah (ground water). Dengan demikian akan dapat mencegah banjir dan keretakan tanah yang memicu terjadinya longsor, serta dapat mencegah penurunan permukaan tanah (subsidence) dan intrusi air laut karena kosongnya pori tanah akibat pemanenan air bawah tanah yang berlebihan (http://www.jatim.go.id/info).

Peresapan air ke dalam tanah dapat diperlancar oleh adanya biopori yang diciptakan fauna tanah dan akar tanaman. Untuk menyediakan lingkungan yang kondusif bagi penciptaan biopori di dalam tanah perlu disediakan bahan organik yang cukup di dalam tanah. Untuk memudahkan pemasukan bahan organik ke dalam tanah perlu dibuat lubang silindris ke dalam tanah. Pembuatan lubang silindris akan menjadi simpanan depresi yang dapat menahan sementara aliran permukaan untuk memberi kesempatan meresap ke dalam tanah. Dinding lubang silindris menyediakan tambahan permukaan resapan air seluas dinding lubang yang dibuat. Bila lubang silindris diisi sampah organik, maka permukaan resapan tidak akan mengalami kerusakan atau penyumbatan karena dilindungi oleh sampah organik ( Kamir R.Brata \& Anne Nelistya, 2008).

Agar bagian air yang meresap kedalam tanah dapat ditingkatkan, terutama di area dimana pengerasan sudah dilakukan, perlu dilakukan kompensasi terhadap lapisan kedap tersebut dengan membuat resapan air buatan menggunakan teknik lubang resapan biopori

\section{B. Tujuan Penelitian}

Tujuan Penelitian ini adalah

1. Membandingkan kecepatan proses pengomposan berbagai jenis sampah organik dalam biopori. Selama ini secara teori sampah yang dimasukkan dalam biopori adalah sampah daun kering. Sehingga dalam penelitian ini akan dibandingkan bagaimana kecepatan proses pengomposan bila sampah yang dimasukkan dicampur dengan sampah dari dapur

2. Tercapainya pemecahan masalah penanganan banjir yang dihadapi warga.

3. Warga masyarakat dapat memanfaatkan lubang resapan biopori untuk mengolah sampah organik menjadi pupuk kompos dan memperoleh manfaat secara ekonomis.

4. Tanah di wilayah tersebut dapat difungsikan sesuai dengan peruntukan lahan di daerah tersebut berdasarkan RT/RW Kota Surabaya yaitu sebagai lahan konservasi.

\section{Urgensi Penelitian}

1. Dari penelitian ini diharapkan dapat direkomendasikan bahwa pengisian biopori tidak hanya sampah daun kering saja yang berasal dari kebun atau halaman, tetapi juga sampah dapur. Dengan demikian hasil penelitian akan memberikan pemecahan masalah bagi sampah dapur. Selama ini para ibu rumah tangga keberatan apabila harus memasukkan sampah ke kerajang takakura atau ke komposter karena prosesnya yang panjang. Sedangkan dengan biopori, langkahnya lebih praktis, yaitu sampah dapur tinggal di masukkan tanpa perlu proses pengadukan dan kemungkinan timbul ulat/ belatung tidak akan terjadi

2. Warga masyarakat dapat mengatasi masalah banjir .

3. Menambah pendapatan warga masyarakat karena memperoleh manfaat secara ekonomis dengan kompos yang dihasilkan dari biopori

4. Lingkungan sekitar dapat terjaga kebersihannya karena sampah organik yang dihasilkan 
dimasukkkan ke dalam lubang resapan biopori

5. Terjadi perubahan paradigma pada warga masyarakat untuk memilah dan mengolah sampah menjadi bahan yang lebih berguna dan bernilai ekonomis.

\section{KAJIAN PUSTAKA}

\section{A. Lubang Resapan Biopori (LRB)}

Setiap bidang lahan secara alami mempunyai fungsi hidrologis yaitu meresapkan air hujan yang jatuh di permukaan lahan. Air hujan yang meresap kedalam tanah akan menjadi cadangan air di daerah perakaran tanaman (ditahan dalam pori mikro) dan kelebihannya akan bergerak ke bawah melalui pori makro mengisi cadangan air bawah tanah. Fungsi hidrologis ini secara alamiah dapat dipertahankan secara terus menerus karena adanya vegetasi yang tumbuh menutupi permukaan tanah serta aktivitas beraneka ragam biota yang hidup di dalam tanah.

Bagian atas (tajuk) tanaman dapat menahan sebagian air hujan melalui proses intersepsi. Tajuk tanaman dan serasah organik yang dihasilkan akan dapat melindungi permukaan tanah dari tumbukan langsung butir hujan, sehingga agregat dan pori tanah tidak rusak. Air yang sampai ke permukaan tanah dapat meresap ke dalam tanah melalui pori makro diantara agregat tanah dan terowongan-terowongan kecil yang dikenal dengan biopori (biopore). Akar tanaman dan fauna tanah (seperti cacing tanah, rayap, semut, dan sebagainya) mampu menciptakan biopori berupa lubang silindris yang sangat efektif menyalurkan air dan udara ke dan di dalam tanah.

Dibandingkan dengan pori makro di antara agregat tanah, biopori bersifat lebih mantap karena diperkuat oleh senyawa organik, serta tidak mudah menutup karena proses pengembangan tanah akibat pembasahan. Karena dibentuk secara aktif oleh biota tanah maka jumlah biopori akan terus bertambah mengikuti perkembangan akar tanaman serta peningkatan populasi dan aktivitas fauna tanah.

Air meresap ke dalam tanah melalui permukaan resapan. Permukaan resapan dapat diperluas dengan membuat lubang secara vertikal ke dalam tanah. Adanya lubang ini maka permukaan resapan menjadi bertambah karena adanya dinding lubang yang akan meresapkan air ke samping melalui permukaan dinding lubang tersebut. Pada kondisi tanah tertentu, perbandingan antara volume air yang harus meresap melalui permukaan resapan dapat menentukan besarnya laju resapan.

Secara fisik peningkatan volume air yang masuk melalui permukaan resapan akan menurunkan laju resapan karena meningkatnya beban resapan. Hal ini ditandai dengan lebarnya zone jenuh air di sekitar permukaan resapan yang mengakibatkan laju pergerakan air minimum. Keadaan jenuh air pada lubang yang terlalu lama tidak mendukung berkembangnya keanekaragaman hayati dalam tanah, terutama fauna tanah yang memerlukan oksigen, air, dan makanan yang cukup. Berkurangnya populasi dan aktivitas fauna tanah menyebabkan biopori di dalam tanah berkurang.

Kondisi ini terjadi pada teknologi peresapan air konvensional yang umumnya didesain untuk meresapkan air hujan dengan bidang tampungan yang relatif besar, seperti kolam, dan sumur resapan. Dengan demikian teknologi peresapan air konvensional hanya mengandalkan proses fisik saja, karena proses biologis menjadi terhambat akibat kelebihan air, kekurangan oksigen, dan bahan organik sebagai sumber energi dan unsur hara mereka.

Teknologi lubang resapan biopori (LRB), dikembangkan berdasarkan prinsip menjaga kesehatan ekosistem tanah untuk mendukung adanya keanekaragaman hayati dalam tanah oleh tersedianya cukup air, udara, dan sumber makanan (bahan organik). LRB dibuat dengan menggali lubang kecil ke dalam tanah diameter $10 \mathrm{~cm}$.

Fauna tanah akan masuk ke dalam LRB yang berisi sampah organik untuk berlindung dari ancaman pemangsanya. Mereka berkembangbiak dan bekerja membuat biopori yang dapat memperlancar peresapan air dan oksigen dalam lubang melalui permukaan resapan yang diperluas oleh adanya dinding LRB. Sampah organik dikunyah, dimakan, dicampur-adukkan dengan mikroba yang secara sinergi dapat mempercepat terjadinya proses pengomposan. Dengan demikian LRB mempunyai kelebihan, selain secara fisik dapat mengurangi beban resapan, secara biologis dapat memperbaiki laju peresapan air dan sekaligus dapat mempermudah 
pemanfaatan sampah organik untuk memperbaiki ekosistem tanah dan mengurangi resiko pencemaran tanah, air, dan udara.

Kumpulan sampah organik yang tidak terlalu besar dalam lubang silindris akan menjadi habitat yang baik bagi fauna tanah terutama cacing tanah yang memerlukan perlindungan dari panas matahari dan kejaran pemangsanya, serta memperoleh makanan, kelembaban, dan oksigen yang cukup. Untuk meminimalkan beban lingkungan oleh adanya pengumpulan volume air dan sampah organik di dalam lubang, maka dimensi lubang tidak boleh terlalu besar, atas beberapa pertimbangan teknis seperti:

(1) kemudahan pembuatan dan pemeliharaan lubang,

(2) pengurangan beban resapan,

(3) kemudahan penyebaran

guna

pengurangan beban lingkungan, dan

(4) kecukupan ketersediaan oksigen bagi fauna tanah;

$$
\text { Lubang resapan sebaiknya }
$$

berdiameter $10 \mathrm{~cm}$ dengan kedalaman lubang $100 \mathrm{~cm}$ atau tidak melebihi kedalaman permukaan air bawah tanah. Diameter lubang resapan yang cukup kecil dan terjadinya peningkatan laju peresapan air karena adanya proses pembentukan biopori melalui permukaan resapan, maka teknologi peresapan air demikian diperkenalkan sebagai lubang resapan biopori (LRB). ( http://www.biopori.com)

Pengosongan pori mikro dapat menyebabkan keretakan tanah. Pengurangan cadangan air bebas dalam tanah akan menyebabkan berkurangnya gerakan air kapiler untuk mempertahankan kelembaban tanah, dan mengakibatkan pengurangan isi pori makro yang pada gilirannya dapat memicu terjadinya penurunan permukaan tanah (subsidence). Fenomena berkurangnya cadangan air bawah tanah yang nyata akibat bertambah luasnya kawasan pemukiman telah dirasakan melalui makin sulitnya memperoleh sumber air bersih pada musim kemarau, serta terjadinya penurunan permukaan tanah dan intrusi air asin yang makin jauh di kawasan pantai.

Peresapan air ke dalam tanah juga sangat penting untuk menghindari terjadinya aliran permukaan yang dapat mengangkut lapisan tanah yang subur, dan berbagai jenis limbah (cair maupun padatan) yang dapat mencemari lingkungan. Pengumpulan aliran permukaan yang meningkat dapat merusak saluran drainase alami maupun buatan, dan bila melebihi daya tampungnya akan meluap menjadi banjir yang meluas.

LRB dapat dibuat untuk meresapkan air ke dalam tanah dengan penambahan luas permukaan resapan vertikal, dan pembentukan biopori di dalam tanah. Dengan demikian tidak menyebabkan pengurangan permukaan lahan yang diperlukan untuk tapak bangunan dan prasarana lainnya di kawasan pemukiman. Melibatkan terjadinya proses fisik dan biologis pada kondisi yang tidak menimbulkan peningkatan beban lingkungan, maka air yang meresap ke dalam LRB akan mengalami proses pengolahan menjadi sumber air bersih secara alami (http://www.biopori.com).

Setiap rumah tangga yang menghuni kawasan pemukiman akan menghasilkan sampah organik baik sampah dapur maupun sisa tanaman dari pot dan halaman/pekarangan. Sampah organik merupakan sumber makanan (energi dan unsur hara) yang sangat dibutuhkan oleh beraneka ragam biota tanah. LRB dapat mempermudah pemanfaatan sampah organik, dengan memasukkannya ke dalam tanah untuk menghidupi biota dalam tanah. Fauna tanah dapat memproses sampah tersebut dengan mengunyah (memperkecil ukuran) dan mencampurkan dengan mikroba tanah yang secara sinergi dapat mempercepat proses pengomposan secara alami.

Sumber makanan yang cukup dari sampah organik sebagian fauna tanah seperti cacing tanah bekerja membentuk biopori dan menghasilkan kotoran cacing (casting). Laju peresapan air ke dalam tanah dapat memelihara kelembaban sampah organik dan tanah disekitar LRB, sehingga proses pengomposan terjadi secara aerobik (cukup oksigen). Campuran kompos, casting dan bahan tanah halus yang masuk dalam lubang dapat dipanen bersamaan dengan pemeliharaan LRB. Sampah organik yang dimasukkan dalam lubang maupun kompos dan casting yang dihasilkan dapat memperbaiki dan memelihara keanekaragaman hayati tanah yang penting untuk perbaikan ekosistem tanah di kawasan pemukiman.

Melalui proses pengomposan aerobik sebagian karbon (C) menjadi organ tubuh beraneka-ragam biota tanah, dan sebagian diubah menjadi humus. Penentuan lokasi untuk penempatan LRB boleh dikatakan merupakan kunci sukses dari model resapan 
ini. Lokasi harus dipilih di tempat yang sesuai, baik dari segi fisik, artistik, maupun keamanan. Segi fisik seperti diungkapkan sebelumnya, LRB adalah lubang untuk meresapkan air, oleh karena itu sangat dianjurkan lokasi LRB berada di tempat dimana air akan terkumpul pada saat hujan berlangsung. Lokasi seperti ini biasanya akan berupa cekungan atau berupa alur. Secara umum hal demikian akan terlihat pada saat hujan berlangsung, yaitu berupa daerah-daerah genangan.

Adanya daerah tergenang yang terbentuk pada saat hujan menunjukkan bahwa tempat tersebut merupakan cekungan tempat air berkumpul. Dengan demikian bila LRB dibuat di lokasi tersebut maka akan efektif. Pada prakteknya LRB tidak harus dibuat di tempat-tempat dengan mengandalkan pada bentukan alam seperti di atas. Bila di lokasi yang akan diberi LRB tidak terdapat cekungan atau alur air, maka perlu dibuat. Prinsip dasar pembuatannya adalah mengarahkan air sedemikian rupa sehingga air akan mengalir ke LRB yang dibuat. Desain dari alur atau daerah tangkapan air ini sebaiknya disesuaikan dengan desain taman atau lansekap yang sudah ada.

Segi artistik Lubang Resapan Biopori tidak hanya dibuat satu buah, tapi dibuat sebagai kompensasi terhadap pengerasan atau bidang kedap yang ada. Pengerasan atau bidang kedap ini bisa berupa tapak bangunan (rumah), halaman yang diperkeras, jalan beraspal atau bentukbentuk penutupan permukaan tanah lain yang menghalangi air (hujan) untuk masuk kedalam tanah. Rata-rata untuk setiap 100 $\mathrm{m}^{2}$ bidang kedap atau pengerasan perlu dibuat hingga 30 buah LRB. Mengingat relatif banyaknya LRB yang harus dibuat maka konfigurasi penempatannya perlu disesuaikan dengan disain taman atau lansekap yang ada. Idealnya penempatan LRB ini sudah diintegrasikan pada rancangan awal disain taman yang bersangkutan( http://www.biopori.com).

Pembuatan LRB di taman rumah mempunyai manfaat ganda. Selain sebagai sarana peresap air, juga sebagai tempat membuang sampah organik asal taman rumah itu sendiri selain yang berasal dari limbah organik rumah tangga lainnya. Sisa pangkasan tanaman, daun-daun yang gugur, dan serasah yang terserak akan dapat langsung dibuang ke LRB yang ada disekitar taman. Selain dapat menjaga kebersihan taman sehingga tetap asri, secara tidak langsung juga merupakan sarana pengembalian unsur hara (pupuk) kedalam tanah yang bersangkutan sehingga kesuburan tanahnya akan senantiasa terjaga (.http://www.rumah

tanah.wordpress.com/2008/03/24/helloword). Segi keamanan LRB berupa lubanglubang menganga, meskipun hanya berdiameter $10 \mathrm{~cm}$, dapat saja memicu kecelakaan berupa kaki terperosok. Oleh karena itu penempatan yang baik akan dapat menghindari kejadian seperti ini. Tidak dianjurkan menempatkan LRB di tempat lalu lalang orang, atau di tengah lapangan bermain anak-anak. LRB sebaiknya ditempatkan pada alur-alur yang sengaja dibuat sebagai pengumpul air antara sebelum masuk kedalam LRB. Dengan ditempatkan pada alur, orang cenderung tidak akan mendatanginya, karena pada umumnya mereka tidak suka berjalan di alur. Disekitar tanaman di taman juga akan menghindari kaki terperosok, karena tempattempat seperti itu bukan merupakan tempat lalu lalang.

Pada dasarnya membuat LRB dapat dilakukan dengan peralatan apapun selama alat tersebut dapat menciptakan lubang dengan diameter $10 \mathrm{~cm}$ dan kedalaman hingga $100 \mathrm{~cm}$. Bambu, linggis, potongan besi atau cangkul kecil dapat dijadikan alat untuk membuat lubang LRB. Meskipun demikian, untuk membuat lubang dengan diameter kecil tapi dalam, sering menemui berbagai kendala. Oleh karena itu, Tim Biopori IPB telah menyiapkan alat berupa bor tanah manual untuk membantu dan mempermudah pembuatan lubang LRB. Bor ini telah didisain agar mampu melakukan pekerjaan diatas dengan mudah. Seseorang dapat membuat lubang LRB dengan bor tersebut hanya dalam waktu 10 menit., bahkan seorang ibu rumah tanggapun dapat melakukannya dengan mudah .

Banyaknya lubang resapan yang perlu dibuat dapat dihitung dengan menggunakan persamaan sebagai berikut: Sebagai contoh untuk daerah dengan intensitas hujan 50 $\mathrm{mm} / \mathrm{jam}$ (hujan lebat), dengan laju peresapan air perlubang 3 liter/menit (180 liter/jam) pada $100 \mathrm{~m} 2$ bidang kedap perlu dibuat sebanyak $(50 \times 100): 180=28$ lubang. Bila lubang yang dibuat berdiameter $10 \mathrm{~cm}$ dan kedalaman $100 \mathrm{~cm}$, maka setiap 
lubang dapat menampung 7,8 liter sampah organik.

Bila sampah organik rumah tangga rata-rata dihasilkan sebanyak 3 liter per hari, berarti tiap lubang dapat diisi sampah organik selama 2-3 hari. Dengan demikian, 28 lubang LRB baru dapat dipenuhi sampah organik yang dihasilkan selama 56 - 84 hari. Pada selang waktu ini sebagian dari lubang tersebut sudah mengalami dekomposisi secara alami, sehingga boleh dikatakan lubang-lubang tersebut pada prinsipnya tidak akan pernah penuh (http://surabaya.go.id/gapura/laput\%204.htm ).

\section{B. Pengomposan}

Bagian sampah yang terbesar adalah bahan-bahan organik. Dengan mengecualikan plastik, karet, kulit, bagian sampah organik sampah perkotaan dapat diklasifikasikan lagi sebagai berikut :

1) Bahan-bahan yang larut dalam air, termasuk didalamnya gula "pati" asam amino, dan berbagai asam organik

2) Homlulose

3) Selulose

4) Lemak, minyak, dan lilin

5) Liguin, suatu bahan senyawa kimia yang secara pasti belum dikenali susunannya

6) Lignoselulose, campuran dari liguin dan selulose

7) Protein-protein yang disusun oleh rangkaian asam-asam amino

Bila bahan-bahan organik ini dipisahkan dari sampah kota dan menjadi sasaran dekomposisi dari bakteri hasil akhir yang diperoleh setelah adanya aktivitas desimilasi \& asimilasi disebut humus. Seluruh proses baik pemisahan sampah maupun pengubahan secara bakteriologik dari sampah organik dikenal sebagai pengomposan.

Dekomposisi sampah organik dapat berlangsung baik secara aerobik atau anaerobik, tergantung tersedianya oksigen. Proses anaerobik berjalan sangat lambat dan menimbulkan bau, maka kebanyakan pengomposan dilakukan secara aerobik.

Umumya, karakteristik kimiawi dan fisik dari humus berbeda-beda sesuai dengan sifat bahan yang diolah, keadaan pada waktu penyelenggaraan pengomposan dan besarnya dekomposisi. Beberapa sifat humus yang dihasilkan yang membedakannya dengan bahan-bahan alami (humus alam) adalah :
1) Berwarna coklat tua sampai hitam

2) Rasio karbon - nitrogen rendah

3) Terus terjadi perubahan yang disebabkan adanya aktivitas mikroorganisme

4) Mempunyai kemampuan tinggi untuk berubah dan menyerap air

\section{B.1. Gambaran Proses Pengomposan}

Pelaksanaan pengomposan pada dasarnya terdiri atas tiga langkah dasar :

1) Persiapan dari sampahnya

2) Dekomposisi sampah

3) Persiapan hasil dan pemasaran Langkah persiapan termasuk kegiatan penerimaan, pemilihan, pemisahan, reduksi ukuran sampah dan penambahan kandungan air, dan nutrion.

Untuk menyempurnakan dalam langkah berikutnya yaitu dekomposisi, beberapa teknik telah dikembangkan. Pada pengomposan yang menggunakan cara "Window", sampah disiapkan dengan menempatkannya dalam alur-alur di lapangan terbuka. Alur-alur ini kemudian diaduk dua kali dalam seminggu selama masa pengomposan 5 minggu. Untuk mencapai stabilisasi ditambahkan waktu 2-4 minggu. Sebagai ganti cara ini telah dikembangkan sistem mekanik. Pengembangan ini memungkinkan terbentuknya humus 5-7 hari. Seringkali bahan yang telah menjadi kompos tersebut diolah lagi pada alur-alur terbuka selama 3 minggu lagi. Setelah sampah dirubah menjadi bahan humus, siap untuk dilanjutkan pada langkah berikutnya.

Persiapan hasil pemasakan termasuk kegiatan penghalusan (finegrinding), pencampuran dengan berbagai bahan tambahan, granulasi (membentuk butiran-butiran), pengantongan, penyimpanan, pengiriman, dan dalam hal-hal tertentu pemasaran langsung.

\section{B.2. Proses Mikrobiologi}

Meskipun bermacam-macam mikroorganisme terlibat, namun pada prinsipnya mikroorganisme yang berperan dalam dekomposisi aerobik adalah bakteri, fungi, yeast, dan actinomycetes. Semua grop dapat mendekomposisi semua bahan mentah yang berbeda. Misalnya grop bakteri lebih menyukai gula yang larut dalam ari, sementara fungi yeast \& 
actinomycetes, khususnya efektif dalam dekomposisi selulose \& hemiselulose.

Disamping

keperluan-

keperluan metabolik, mikroorganisme utama menjadi banyak sekali selama proses pengomposan. Satu diantara faktor-faktor yang dipertimbangkan atas kejadian ini adalah timbulnya panas sebagai hasil desimilasi \& asimilasi mikroorganisme dalam pengubahan sampah menjadi humus yang stabil. Mula-mula bahan yang dikomposkan naik suhunya sebagai akibat dilepaskannya energi serta degredasi sampah organik dan gula yang dapat dirubah menjadi humus. Bila suhu naik diatas $45-50^{\circ} \mathrm{C}$, organisme mesofilik akan mulai berkuasa. Organisme-organisme ini akan berkuasa pada $55^{\circ} \mathrm{C}$ yang menjadi suhu optimum bagi organisme ini. Bakteri-bakteri dan octinomycetes tertentu biasa dijumpai pada suhusuhu ini. Dalam keadaan normal, stabilisasi lebih cepat pada susunan thermofilik dibanding pada keadaan mesofilik.

\section{METODE PENELITIAN}

\section{A. Rancangan Penelitian}

Penelitian ini termasuk jenis penelitian eksperimen. Metode yang digunakan dalam penelitian ini adalah metode pendekatan Eksperimen, yaitu mengadakan kegiatan percobaan untuk melihat suatu hasil yang akan menegaskan bagaimana hubungan kausal antara variabel yang satu dengan yang lainnya. Adapun tahapan yang dilakukan sebagai berikut:

\section{B. Deskripsi Populasi dan Penentuan Sampel.}

\section{Deskripsi Populasi}

Dalam penelitian ini, populasi adalah seluruh lubang resapan biopori yang ada di RW IV
Kelurahan Gunungsari, Kecamatan Dukuh Pakis, Kota Surabaya sejumlah 240 lubang

\section{Penentuan Sampel.}

Sampel dalam penelitian ini sejumlah 30 buah yang berada di posisi

1. Halaman balai RW IV (SAMPEL A)

Akan di isi oleh sampah daun, rumput saja

2. Halaman rumah warga bernomor urut genap (SAMPEL B)

Akan diisi dengan sampah campuran sampah dapur dan sampah daun dan rumput

3. Halaman rumah warga bernomor urut ganjil (SAMPEL C)

Akan di isi dengan hanya sampah dapur saja

\section{Metode Pengumpulan Data}

Pemberian perlakuan

Treatment 1. Lubang Resapan Biopori di isi oleh sampah daun dan rumput saja

Treatment 2. Yang akan diisi dengan sampah campuran sampah dapur dan sampah daun dan rumput

Treatment 3 . Yang akan di isi dengan hanya sampah dapur saja

\section{Prosedur Pengumpulan data.}

Langkah-langkah yang dilakukan dalam penelitian adalah sebagai berikut:

\section{a. Kegiatan}

\section{percobaan/eksperimen dalam penelitian}

Setelah diberi perlakuan, dilakukan pengamatan setiap hari dan dilihat kecepatan penurunan sampah yang identik dengan pengubahan menjadi kompos

b. Alat dan bahan yang digunakan untuk penelitian.

Seperangkat lubang resapan biopori 


\section{PENYAJIAN DATA}

1. Halaman Balai RW IV (SAMPEL A)

LRB di isi oleh sampah daun/ rumput saja

\begin{tabular}{|c|c|c|c|c|c|c|c|c|c|}
\hline No & $\begin{array}{l}\text { NOMOR } \\
\text { SAMPEL }\end{array}$ & $\begin{array}{l}\text { HARI } \\
\text { KE } 1\end{array}$ & $\begin{array}{l}\text { HARI } \\
\text { KE2 }\end{array}$ & $\begin{array}{l}\text { HARI } \\
\text { KE3 }\end{array}$ & $\begin{array}{l}\text { HARI } \\
\text { KE4 }\end{array}$ & $\begin{array}{l}\text { HARI } \\
\text { KE5 }\end{array}$ & $\begin{array}{l}\text { HARI } \\
\text { KE6 }\end{array}$ & $\begin{array}{l}\text { HARI } \\
\text { KE7 }\end{array}$ & $\begin{array}{l}\text { HARI } \\
\text { KE8 }\end{array}$ \\
\hline & 1 & 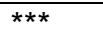 & 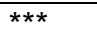 & 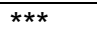 & 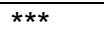 & 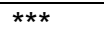 & 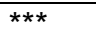 & 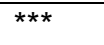 & 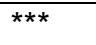 \\
\hline & 2 & $\star * \star$ & $\star \star \star *$ & $\star \star \star *$ & $\star \star \star *$ & $\star \star \star *$ & 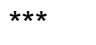 & $\star \star \star *$ & $\star \star \star *$ \\
\hline & 3 & $\star * \star$ & $\star * *$ & $* * *$ & $* * *$ & $* * *$ & $\star * *$ & $* * *$ & $* * *$ \\
\hline & 4 & $* * *$ & $\star * \star *$ & $* * *$ & 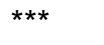 & $\star \star \star *$ & $\star \star * *$ & $\star \star \star *$ & $\star * *$ \\
\hline & 5 & $* * *$ & $\star * \star *$ & $* * *$ & 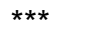 & $\star \star \star *$ & $\star \star * *$ & $\star \star * *$ & $\star * *$ \\
\hline & 6 & $* * *$ & $\star * \star *$ & $* * *$ & 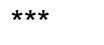 & $\star \star \star *$ & $\star \star * *$ & $\star \star \star *$ & $\star * *$ \\
\hline & 7 & $\star \star \star *$ & $* * *$ & $* * *$ & $* * *$ & $* * *$ & $\star * * *$ & $* * *$ & $* * *$ \\
\hline & 8 & $* * *$ & $\star * * *$ & $* * *$ & $* * *$ & $\star * * *$ & $\star * * *$ & $* * *$ & $\star * * *$ \\
\hline & 9 & $\star \star * *$ & $\star \star * *$ & $* * *$ & $\star \star \star *$ & $\star \star * *$ & 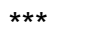 & $\star \star \star *$ & $\star * \star$ \\
\hline
\end{tabular}

2.Halaman rumah warga bernomor urut genap (SAMPEL B)

LRB diisi dengan sampah campuran sampah dapur dan sampah daun dan rumput

\begin{tabular}{|c|c|c|c|c|c|c|c|c|c|}
\hline No & $\begin{array}{l}\text { NOMOR } \\
\text { SAMPEL }\end{array}$ & $\begin{array}{l}\text { HARI } \\
\text { KE } 1\end{array}$ & $\begin{array}{l}\text { HARI } \\
\text { KE2 }\end{array}$ & $\begin{array}{l}\text { HARI } \\
\text { KE3 }\end{array}$ & $\begin{array}{l}\text { HARI } \\
\text { KE4 }\end{array}$ & $\begin{array}{l}\text { HARI } \\
\text { KE5 }\end{array}$ & $\begin{array}{l}\text { HARI } \\
\text { KE6 }\end{array}$ & $\begin{array}{l}\text { HARI } \\
\text { KE7 }\end{array}$ & $\begin{array}{l}\text { HARI } \\
\text { KE8 }\end{array}$ \\
\hline & 1 & 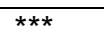 & 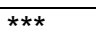 & $\star \star \star$ & $\star \star \star *$ & * & * & $\star$ & * \\
\hline & 2 & $\star \star \star *$ & $\star * *$ & $\star * *$ & $\star \star \star *$ & * & * & * & * \\
\hline & 3 & $\star \star * *$ & $\star \star \star *$ & $\star \star * *$ & $\star \star \star *$ & * & * & * & * \\
\hline & 4 & $* * *$ & $\star \star * *$ & $\star \star \star *$ & $\star \star \star *$ & * & * & * & * \\
\hline & 5 & $* * *$ & $\star * *$ & $\star * *$ & $* / * *$ & $\star / * *$ & $* / * *$ & $* / * \star$ & $* / * *$ \\
\hline & 6 & $\star \star \star *$ & 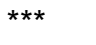 & $\star * \star *$ & */** & */** & */** & $\star / * \star$ & $* / * *$ \\
\hline & 7 & $\star \star \star *$ & 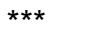 & $\star \star \star *$ & */** & */** & $* / * *$ & $* / * *$ & $* / * *$ \\
\hline & 8 & $* \star *$ & $\star \star \star *$ & $\star \star * *$ & $\star * \star * *$ & ** * & 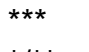 & ** * & $* * *$ \\
\hline & 9 & 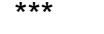 & $\star \star \star ~$ & 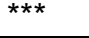 & */** & */* * & */** & */* * & $* / * *$ \\
\hline
\end{tabular}

3.Halaman rumah warga bernomor urut ganjil (SAMPEL C) LRB di isi dengan hanya sampah dapur saja

\begin{tabular}{|c|c|c|c|c|c|c|c|c|c|}
\hline No & $\begin{array}{l}\text { NOMOR } \\
\text { SAMPEL }\end{array}$ & $\begin{array}{l}\text { HARI } \\
\text { KE } 1\end{array}$ & $\begin{array}{l}\text { HARI } \\
\text { KE2 }\end{array}$ & $\begin{array}{l}\text { HARI } \\
\text { KE3 }\end{array}$ & $\begin{array}{l}\text { HARI } \\
\text { KE4 }\end{array}$ & $\begin{array}{l}\text { HARI } \\
\text { KE5 }\end{array}$ & $\begin{array}{l}\text { HARI } \\
\text { KE6 }\end{array}$ & $\begin{array}{l}\text { HARI } \\
\text { KE7 }\end{array}$ & $\begin{array}{l}\text { HARI } \\
\text { KE8 }\end{array}$ \\
\hline & 1 & $* / * *$ & $* / * *$ & $\pi / * \star$ & $* / * *$ & $* / * *$ & $\star / * \star$ & $* / * *$ & $\star / * \star$ \\
\hline & 2 & $* / * *$ & $* /^{*} *$ & $\star / * *$ & $* / * *$ & $* / * *$ & $\star / * \star$ & $* /^{*} *$ & $\star / * *$ \\
\hline & 3 & $* / * *$ & $* / * *$ & $* / * *$ & $* / * *$ & $* / * *$ & $* / * *$ & $* / * *$ & $* / * *$ \\
\hline & 4 & $* / * *$ & $* / * *$ & */** & $* / * *$ & $* / * *$ & */** & $* / * *$ & */** \\
\hline & 5 & ${ }^{*} / * *$ & $* / * *$ & */** & $* / * *$ & $* / * *$ & */** & $* / * *$ & */** \\
\hline & 6 & $* / * *$ & $* /^{*} *$ & */** & $* /^{*} *$ & $* /^{*} *$ & $\star / * \star$ & $* / * *$ & $\star / * \star$ \\
\hline & 7 & $* / * *$ & $* /^{*} *$ & */** & $* /^{*} *$ & $* /^{*} *$ & $\star / * \star$ & $* / * *$ & $\star / * \star$ \\
\hline & 8 & $* / * *$ & $* / * *$ & */** & $* / * *$ & $* / * *$ & */** & $* / * *$ & */** \\
\hline & 9 & $* / * *$ & $\star / * *$ & ${ }^{* / * *}$ & ${ }^{*} / * *$ & $* / * *$ & ${ }^{* / * *}$ & ${ }^{*} / * *$ & ${ }^{* / * \star}$ \\
\hline
\end{tabular}

KETERANGAN :

* PENGURANGAN VOLUME

** PERUBAHAN FISIK / PEMBUSUKAN

*** TIDAK TERJADI PERUBAHAN APAPUN

*** PENGURANGAN VOLUME dan PERUBAHAN FISIK / PEMBUSUKAN 


\section{PEMBAHASAN}

Lubang Resapan Biopori diaktifkan oleh organisme tanah, khususnya fauna tanah dan perakaran tanaman. Aktivitas merekalah yang selanjutnya akan menciptakan rongga-rongga atau liang-liang di dalam tanah yang akan dijadikan saluran air untuk meresap ke dalam tubuh tanah. Dengan memanfaatkan aktivitas mereka maka rongga-rongga atau liang-liang tersebut akan senantiasa terpelihara dan terjaga keberadaannya, sehingga kemampuan peresapannya akan tetap terjaga tanpa campur tangan langsung dari manusia untuk pemeliharaannya. Hal ini tentunya akan sangat menghemat tenaga dan biaya. Kewajiban faktor manusia dalam hal ini adalah memberikan pakan kepada mereka berupa sampah organik pada periode tertentu. Sampah organik yang dimasukkan ke dalam lubang akan menjadi humus dan tubuh biota dalam tanah, tidak cepat diemisikan ke atmosfir sebagai gas rumah kaca, berarti mengurangi pemanasan global dan memelihara biodiversitas dalam tanah.

Hadirnya lubang-lubang resapan biopori dapat dicegah adanya genangan air, sehingga berbagai masalah yang diakibatkannya seperti mewabahnya penyakit malaria, demam berdarah, dan kaki gajah (filariasis) akan dapat dihindari.

Pertimbangan perancangan secara prinsip yang berhubungan dengan dekomposisi biologik dari sampah dapat disimpulkan bahwa persiapan proses pengomposan bukanlah tugas yang sederhana, khususnya bila akan mencapai hasil yang optimum. Oleh karena itu, pelaksanaan dari sebagian besar pengomposan komersial yang telah dikembangkan adalah dimekanisasi benarbenar dan dikerjakan dengan fasilitasfasilitas yang dirancang khusus http://www.bakosurtanal.go.id/multihazard/Vi ew.php?|D=11\&ID2=5\&ID3.

Faktor-faktor dalam tabel tersebut dapat dikontrol secara efektif. Sekalipun persyaratan mengenai area tanah yang digunakan tak tercantum dalam tabel, persyaratan itu juga harus dipertimbangkan. Sebagai contoh pengomposan yang menggunakan alur-alur pada tanah terbuka yang mempunyai kapasitas 0 ton/ hari, diperlukan 2,5 acre. Tanah seluas 1,5 acre diperuntukkan untuk gedung, peralatan, dan jalan. Setiap penambahan 50 ton diperkirakan memerlukan tambahan 1,0 acre untuk operasi pengomposan dan 0,25 acre untuk tambahan gedung dan jalan.

Keperluan tanah yang menggunakan sistem mekanik tergantung prosesnya. Suatu perkiraan 1,5 - 2,0 acre tanah yang dipergunakan untuk pabrik kompos sistem mekanik berkapasitas 50 ton/ hari telah cukup

http:///www.bappeko.surabaya.go.id/bappeko /index.php

Perhatian terhadap lingkungan yang terpenting adalah yang berhubungan dengan timbulnya bau, beterbangannya bahanbahan, dan kemungkinan terjadinya keracunan logam berat pada tanah. Jika pengawasan dilakukan tidak sebagaimana mestinya, terbentuknya bau akan menjadi suatu masalah, khususnya pengomposan pada alur terbuka.

Suatu kecenderungan yang dapat berakibat pada semua pelaksanaan pengomposan, khususnya bila menggunakan penghancur mekanik, adalah termasuk kemungkinan timbulnya peracunan logam berat. Bila logam dalam sampah dihancurkan, partikel debu logam ditimbulkan oleh aktivitas penghancur. Partikel-partikel ini dapat menempel pada benda-benda ringan sebagai hasil penghancuran sampah. Akhirnya, setelah pengomposan logam-logam ini akan dibuang ke tanah. Beberapa diantaranya tidak mempunyai pengaruh, tetapi logam-logam seperti cadurium (karena sifat racunnya) betul-betul perlu mendapat prehatian.

Percobaan yang lebih banyak perlu dikerjakan untuk mengukur pengaruh pelaksanaan proses secara mekanik pada susunan kompos.

Sampah organik berupa sampah dapur, sisa pangkasan tanaman atau daun yang berjatuhan merupakan bahan utama agar LRB berfungsi. Bahan-bahan ini secara rutin perlu ditambahkan ke dalam LRB. Penambahan diperlukan karena sampah yang sebelumnya dimasukkan ke dalam LRB akan mengalami pelapukan dan dikonsumsi oleh biota tanah, sehingga dengan bertambahnya waktu sampah organik di dalam LRB akan berkurang.

Bahan organik yang dimasukkan ke dalam LRB selain dikonsumsi biota tanah juga secara alami mengalami proses pelapukan/dekomposisi. Hasil akhir dari proses ini berupa kompos. Kompos yang dihasilkan secara periodik dapat dipanen. Pemanenan dapat dilakukan dengan menggunakan bor LRB, atau cara lain yang dianggap mudah. Meskipun demikian karena 
tujuan utama dari LRB adalah sebagai peresap air, maka pemanenan kompos sebaiknya dilakukan pada musim kemarau, di saat LRB tidak begitu aktif meresapkan air. Hal ini dilakukan agar tidak mengganggu aktifitas biota tanah di dalam LRB pada saat diperlukan.

Dengan tersedianya teknik sederhana yang mudah dan murah seperti LRB seyogyanya tidak ada lagi alasan bagi warga masyarakat dimanapun untuk tidak membuat resapan air buatan di halaman rumahnya. Pembuatan resapan air buatan ini adalah sebagai kompensasi terhadap bidang kedap yang telah dibuat di permukaan lahan yang telah menghalangi kesempatan air hujan untuk masuk kedalam tanah dan menjadi cadangan air tanah.

Kehadiran lubang resapan biopori secara langsung akan menambah bidang resapan air, setidaknya sebesar luas kolom/dinding lubang. Sebagai contoh bila lubang dibuat dengan diameter $10 \mathrm{~cm}$ dan dalam $100 \mathrm{~cm}$ maka luas bidang resapan akan bertambah sebanyak $3140 \mathrm{~cm}^{2}$ atau hampir $1 / 3 \mathrm{~m}^{2}$. Dengan kata lain suatu permukaan tanah berbentuk lingkaran dengan diamater $10 \mathrm{~cm}$, yang semula mempunyai bidang resapan $78.5 \mathrm{~cm}^{2}$ setelah dibuat lubang resapan biopori dengan kedalaman $100 \mathrm{~cm}$, luas bidang resapannya menjadi $3218 \mathrm{~cm}^{2}$. www.indahbri.blogspot.com
Adanya aktivitas fauna tanah pada lubang resapan maka biopori akan terbentuk dan senantiasa terpelihara keberadaannya. Oleh karena itu, bidang resapan ini akan selalu terjaga kemampuannya dalam meresapkan air. Dengan demikian kombinasi antara luas bidang resapan dengan kehadiran biopori secara bersama-sama akan meningkatkan kemampuan dalam meresapkan air.

\section{KESIMPULAN}

\begin{abstract}
Jenis sampah yang dimasukkan akan mempengaruhi kecepatan proses pengkomposan yang di tandai dengan kecepatan menurunnya ketinggian sampah dalam lubang resapan biopori. Dengan semakin cepat terjadi penurunan ketinggian sampah maka lubang resapan akan dapat digunakan setiap hari.

Manfaat ganda dari LRB sebagai tempat "pembuangan" sampah organik rumah tangga, diharapkan pada suatu saat nanti tidak akan ada lagi sampah organik yang keluar dari lingkungan rumah. Dengan demikian akan dapat mengurangi beban pada tempat pembuangan sampah sementara (TPS) atau pembuangan akhir (TPA). Kompos yang dihasilkan dari LRB dan pilahan sampah anorganik dapat saja dijadikan sumber penghasilan tambahan bagi perekonomian rumah tangga.
\end{abstract}

\section{DAFTAR PUSTAKA}

Kamir R.Brata \& Anne Nelistya, Lubang Resapan Biopori, Penebar Swadaya 2008 http://www.jatim.go.id/info cuaca/index.php?ip=det.bencana (diunduh tanggal 6 Pebruari 2009) http://www.surya.co.id (diunduh tanggal 7 Pebruari 2009) http://www.bakosurtanal.go.id/multihazard/View.php?ID=11\&ID2=5\&ID3 $=$ (diunduh tanggal 18 Pebruari 200) http://www.biopori.com (diunduh tanggal 6 Pebruari 2009) http://www.rumah tanah.wordpress.com/2008/03/24/helloword. (diunduh tanggal 11 Februari 2009) http://www.penataan ruang.pu.go.id/ta/lapak 04/p1/lahan tol/bab 3 (diunduh tanggal 1

Pebruari 2009) http://surabaya.go.id/gapura/laput\%204.html (diunduh tanggal 9 pebruari 2009) http://www.ciptakarya.pu.go.id/profil/profil/barat/jatim/surabaya.pdf (diunduh tanggal 3 Januari 2009) www.indah-bri.blogspot.com (diunduh tanggal 13 januari 2009) http:///www.bappeko.surabaya.go.id/bappeko/index.php 